\title{
Erratum: Follow Your Nose: A Key Clue to Understanding and Treating COVID-19
}

\author{
Frontiers Production Office ${ }^{*}$ \\ Frontiers Media SA, Lausanne, Switzerland
}

\section{OPEN ACCESS}

Approved by: Frontiers Editorial Office, Frontiers Media SA, Switzerland

${ }^{*}$ Correspondence: Frontiers Production Office production.office@frontiersin.org

Specialty section:

This article was submitted to Cellular Endocrinology, a section of the journal Frontiers in Endocrinology

Received: 06 December 2021 Accepted: 06 December 2021 Published: 16 December 2021

Citation: Frontiers Production Office (2021)

Erratum: Follow Your Nose:

A Key Clue to Understanding and Treating COVID-19.

Front. Endocrinol. 12:830164. doi: 10.3389/fendo.2021.830164
Keywords: COVID-19, mineralocorticoid receptor, spironolactone and dexamethasone, ATP - adenosine triphosphate, anosmia and ageusia

\section{An Erratum on}

Follow Your Nose: A Key Clue to Understanding and Treating COVID-19

by Edwards, C., Klekot, O., Halugan, L. and Korchev, Y. (2021). Front. Endocrinol. 12:747744. doi: 10.3389/fendo.2021.747744

Owing to a production error, several dependent variables were omitted from the part of Table 2 that pertains to Study 1 in the article as originally published. The variables in question are mean diastolic blood pressure, breath rate, C-reactive protein concentration, D-dimer concentration, fasting glucose concentration and plasma potassium concentration. The complete part of Table 2 that pertains to Study 1 is presented here.

The publisher apologizes for this error. The original article has been updated.

Copyright (c) 2021 Frontiers Production Office. This is an open-access article distributed under the terms of the Creative Commons Attribution License (CC BY). The use, distribution or reproduction in other forums is permitted, provided the original author(s) and the copyright owner(s) are credited and that the original publication in this journal is cited, in accordance with accepted academic practice. No use, distribution or reproduction is permitted which does not comply with these terms. 
TABLE 2 | Study 1. Repeated measures analysis comparing changes in variables from baseline to 5 days treatment (T1).

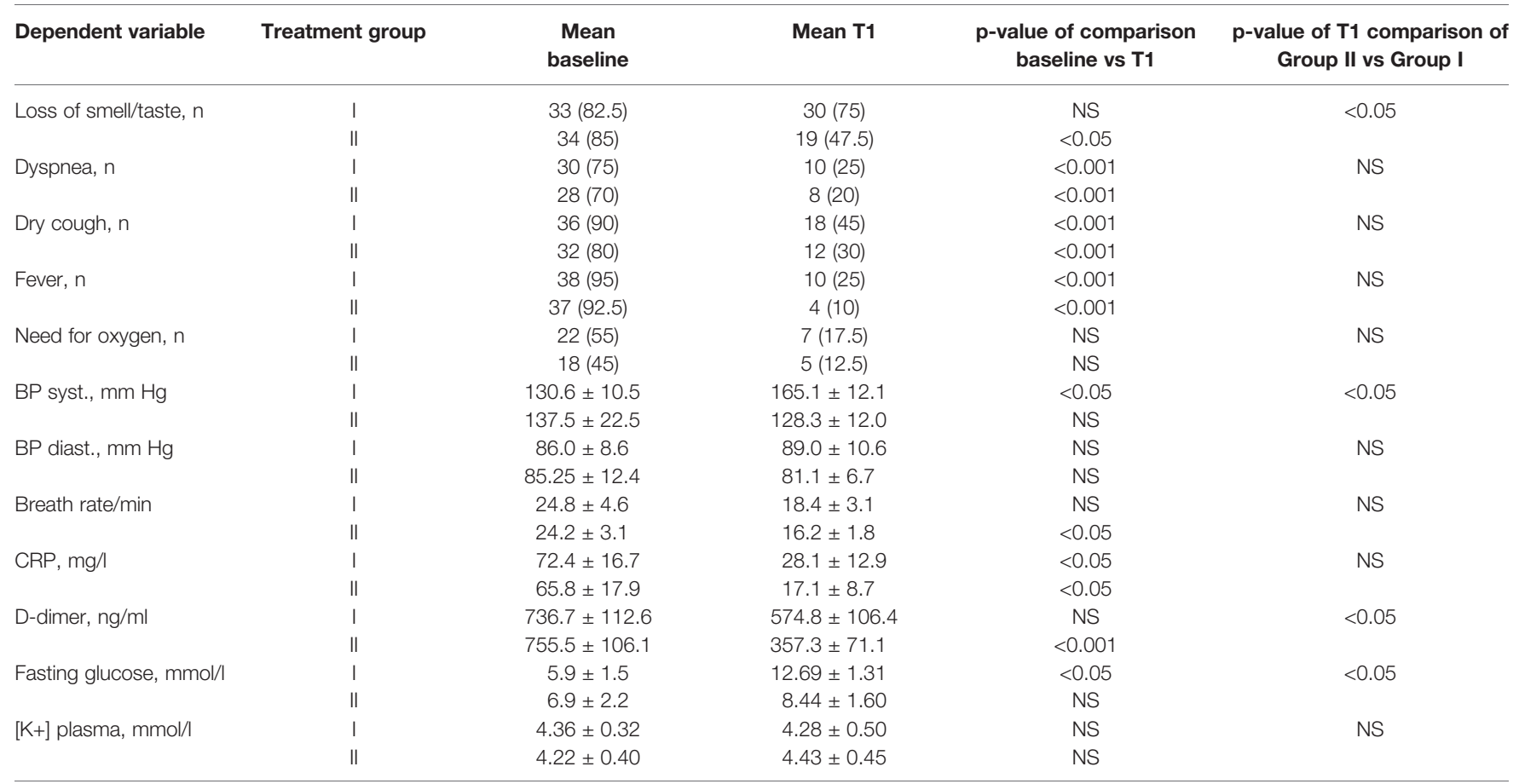

SD, standard deviation; mean BP, mean blood pressure; [K+] plasma, plasma concentration of potassium; CRP, C-reactive protein. Figures are expressed as Mean and Standard Deviation. NS, non-significant difference. No patient required ventilation: patients with oxygen saturation less than $92 \%$ given oxygen by mask. 